Peer-Reviewed Article

ISSN: 2162-3104 Print/ ISSN: 2166-3750 Online

Volume 5, Issue 3 (2015), pp. 244-259

(C) Journal of International Students

http://jistudents.org/

\title{
Intragroup Conflict During Study Abroad
}

\author{
Peter Bodycott, PhD \\ Faculty of Education, Science, Technology \& Mathematics \\ University of Canberra (Australia)
}

\begin{abstract}
Co-national groups of individuals from the same country can provide members with psychological and sociocultural support when coping with the stresses of studying abroad. This article examines intragroup task and relationship conflict that occurred in one co-national group during a 14-week short-term study abroad program. Findings reveal the negative effect of intragroup conflict, within the co-national group, on student's personal and social -ethnicidentities, acculturation and program involvement. Recommendations are made about ways to help students in co-national groups cope with acculturation and intragroup conflict, and how institutions can better prepare and support students for study abroad.
\end{abstract}

Keywords: acculturation, study abroad, case study, Chinese, intragroup conflict, international students

Increasing numbers of students, often from an early age, are crossing cross borders to study. In 2011 there were more than 4.3 million internationally mobile students (OECD, 2013) studying abroad in programs of varying length. Short-term study abroad programs may last for a few days or weeks up to a year and often have specific purposes such as second language development or cultural immersion. Student exchange or short-term study abroad programs involve academic study for a semester or two. Students on longer-term study abroad programs may spend years studying undergraduate or postgraduate degrees.

Studying abroad presents opportunities to develop self-confidence, build self-esteem (Milstein, 2005), expand second language ability and develop intercultural interaction competencies (Kinginger, 2009). It can also increase student knowledge of a new culture and help develop new cross-cultural understandings (Pitts, 2009). Study abroad provides countless opportunities to develop as a person -to enhance identity development (Benson, Barkhuizen, Bodycott \& Bell, 2013)

Study abroad can also be challenging. Students need to cope with the stresses of living away from home and adapting to new academic and social environments. How a student responds to these challenges can have an affect on their psychological well-being and academic 
self-efficacy (Mak \& Kim, 2011). For support, study abroad students' seek support from people from the same culture or co-national groups (Kinginger, 2010).

A student traveling abroad as part of a co-national group has built in personal, social and academic support (Bodycott \& Crew, 2000). For students traveling alone, support can be found in co-national student groups and societies which are common on higher education campuses. As well as a support role, these groups often organize activities to promote their cultural way of life and traditions in the local community. They also provide a place where people can share common interests about the culture-creating opportunities for all students to develop crosscultural understanding. However, what happens when intragroup conflict occurs within a conational group?

This article examines the effects of intra-group conflict in a small co-national group of students taking part in a short-term study abroad program. The following sections examine the literature on identity development, identity and co-national group conflict. A case study of three student's experience is presented and discussed. Recommendations are made on how to better prepare students for the challenges of short-term study abroad and potential intragroup conflict.

\section{Literature Review}

\section{Identity and Identity Change during Study Abroad}

Developing a sense of who we are and our social fit -our identity- is a part of a person's being (Kelly, 1995). Two broad classifications of identity have been identified: personal and social. "Personal identity" refers to the thoughts, feelings and views a person has about themselves -I am clever, trustworthy and unbiased. "Social identity" refers to how we see ourselves socially -the roles we play, the groups we belong to, our membership in organizations and vocations. There are different types of social identity, for example, ethnic identity -includes the cultural qualities we share with others (Tajfel \& Turner, 1986).

Personal and social identities represent a view of our beliefs and values. These can influence behavior, expectations and opinions (Swann \& Bosson, 2008). They help us to interpret new life experiences and can control how open we are to new information. Identities are constantly being challenged and refined through social engagement and personal reflection. If a new experience challenges our beliefs and values, then opportunities are created for our identity and the underlying constructs to change.

Study abroad provides students with countless opportunities to develop and cultivate their personal and social identities. While abroad, students need to deal with two cultures simultaneously. New information and experiences must be filtered through identities shaped by a lifetime of exposure in their home culture. The study abroad experience takes students out of their comfort zone and exposes them to the possibility of cultural and group conflicts (Medina, Munduate, Dorado \& Guerra, 2005). How a person reacts to such experiences depends largely on the strength of their identity (Mayer, 2009), their understanding of the experience and the support they receive. A correlation exists between identity strength and performance. A Chinese student studying abroad for example, may have a strong ethnic identity. Therefore, they place great importance on cultural maintenance (Berry, 1997) and therefore seek membership in a conational group. This can help students maintain a sense of who they are as a Chinese person studying in a foreign land. The strength of a person's identities influences the values that person holds and their acculturation into pluralist societies when studying abroad. It controls how open they are to new experiences and the likelihood of identity development and change (Ethier \& 
Deaux, 2001). In this article, acculturation refers to the process and behavioral and psychological change that occurs when people of different cultures come into continuous face-to-face contact (Berry, 1997).

\section{Identity Conflict and Study Abroad}

Study abroad exposes students to the reality of cultural difference and the possibility of challenges to their sense of who they are. Study in a foreign country and culture -far from their personal support network- confronts the student with different cultural practices, different social attitudes and values. Students face differences in educational expectations and approaches to learning and study. They move from the relative security of their home culture to one where they may be the odd person out. The study abroad setting and the actions of others -students, academics, host families - can pose challenges to the student's personal and social identities and acculturation strategies (Berry, 1997). Forming relations with locals, as Dempsey (2012) found, can help develop acculturation through shared intercultural understandings and communication.

Nevertheless, individual students need to learn to acculturate, to fit in, if they are to succeed and cope in a study abroad context. Similarly, local students need to adapt to the presence of study abroad students (Bodycott, Mak \& Ramburuth, 2014). Setting up social relations with locals, often in a second language, is a common study abroad program objective for many students; yet it can be a source of stress and personal conflict (Chen, 1999; Trice, 2007). How students deal with the challenge of acculturation, or fitting in, and the differences and conflicts created by study abroad can affect the way they see themselves -their identity-into the future.

Baumeister (1986) identified two distinct categories of identity-related problems, which may affect students on study abroad. These are identity deficits and identity conflicts. "Identity deficits" in study abroad occur when students come to realize that their personal or social identity no longer reflect how they see themselves. Therefore, they need to adapt or change their identity to reflect new meaning or commitment. "Identity conflict" in study abroad occurs when new experiences oppose or cannot be integrated into the student's existing way of thinking. The student therefore cannot or may be unwilling to adapt or change (Baumeister, 1986). To deal with such conflicts, students often turn to co-national groups or others in the host country for support or reinforcement of their personal or social-ethnic identity.

According to Leong and Ward (2000), there are multiple interpretations and explanations about identity conflict during study abroad. In their study of the cross-cultural adaptation of People's Republic of China (PRC) students studying in Singapore, they found a strong personal identification with the culture of origin to be linked with lower levels of identity conflict. In this case, PRC students identified with Chinese Singaporean students, and this reduced the identity conflict experienced.

Lin (2008) found the quality of contact with host nationals, host language competence, and students" sense of discrimination to be "powerful and effective" predictors of identity conflict (p.139). Intergroup relations between study abroad students and other students, not of their own culture, can be significant predictors and sources of identity conflict, and of support. However, co-national group relations also have the potential to cause identity conflict (Jehn \& Mannix, 2001).

\section{Co-National Group Conflict}

While abroad, study abroad students often seek support from other co-nationals. That is, 
students from the same ethnic background or country. Within such groups, interpersonal relations, even friendships form and these influence the students' social networks and acculturation (Bochner, McLeod \& Lin, 1977). Co-national groups provide students with a feeling of cultural identity and can offer emotional support (Maundeni, 2001). They also provide opportunities for study abroad students to discuss and share within the group their understandings of the new culture (Woolf, 2007). Strong co-national groups can also increase the self-esteem of study abroad students (Al-Sharideh \& Goe, 1998). Co-national groups can however be a potential source of intragroup conflict. This may be brought on by personality differences, personal identity, expectations and goals, and stresses associated with acculturation. Kim (2001) warned that co-national groups may serve to aggravate the stresses that individual study abroad students experience. These groups reinforce students' social-ethnic identity, making group members less willing to adjust or adapt to the local culture (Ward \& Searle, 1991). Kim (2001) also suggests that while co-national groups offer language, academic and social support in the short-term, potential negative effects may occur. Groups of co-national students may remain within the security of the group, rather than seeking to integrate into the host culture. This may result in degrees of intragroup conflict, an area often overlooked in studies of study abroad and student acculturation (Llamas \& Morgan Consoli, 2012).

Jehn (1995) distinguished between two kinds of intragroup conflict: task conflict and relationship conflict. Both have the potential to affect the psychological and social well-being of individual study abroad group members. "Task conflict" occurs when there is a disagreement among individual group members about the content of their decisions. It often involves differences in views, ideas and opinions of tasks. Examples include conflicts about the task purpose, distribution of resources and procedures, or interpreting data. "Relationship conflict" on the other hand occurs when interpersonal incompatibility arises. This happens when annoyance and will occur among people (Jehn \& Mannix, 2001). Task conflict can be positive, however, benefit may be lost if the conflict transforms into relationship conflict. Given the personal, social and academic stresses associated with study abroad there is a high likelihood of task and relationship conflict occurring within co-national groups. Such conflicts may in turn affect intercultural communication, relations with host nationals, and the ability of the student to adapt to life in a new culture (Williams \& Johnson, 2011).

\section{Research Method}

\section{Background}

This article examines the co-national intragroup conflict experienced by three students studying to be teachers of English in Hong Kong. The students were taking part in a compulsory 14-week Government sponsored study abroad program. The objectives of the program were:

a) To strengthen students' English language skills, in particular their spoken English and listening comprehension, by formal and informal immersion in a native-speaker cultural context

b) To provide students with a focused experience that involves living and using English within a native speaker cultural environment

c) To provide students with the opportunity to develop academic and intercultural understandings and skills through the study of academic courses with local students in a university context

d) To provide opportunities for students to visit local schools 

through:

As part of the program preparation and evaluation, data was collected from all students

1. pre-departure survey with open-ended questions and interview

2. e-journal writing, and

3. post study abroad survey with open-ended questions and voluntary interview

The pre-departure study abroad survey and interview provided information about past English language learning, overseas travel and experience using English with native English language speakers. Students also listed and discussed their expectations and goals of the forthcoming study abroad experience and their English language ability.

While abroad, students noted anything that seemed interesting or significant about the study abroad experience in a weekly e-journal. Students had the freedom to discuss their journal entries and study abroad experiences with the program coordinator by email or Skype.

Pre and post study abroad surveys and voluntary interviews (approx. 60 mins) were designed to gain insight into the study abroad experience, achievement of goals, perceived program benefits and to obtain information to improve the program. Collated findings from the pre and post surveys and interviews formed the basis of an annual report to Hong Kong SAR Government.

\section{Participants and Context}

The three Hong Kong born Chinese study abroad participants, Ming Li, Kerry Siu and John Lau, were in the second year of a four-year Bachelor of Education undergraduate degree. They traveled to Canada with a small co-national group of 16 other students. The three participants knew the other students, having all studied the same degree course leading up to the study abroad experience.

While in Canada, all students stayed with local families. The study abroad program took place in a Canadian University. The group took part in courses to enrich language and cultural awareness, and credit-bearing degree courses with local students.

It was in the second week of the 14-week study abroad experience that Ming Li, Kerry and John began to independently report an issue of group conflict in e-journals and emails. Other group members replied to coordinator inquiries there was no problem. Following the study abroad experience, only Ming Li, Kerry and John mentioned group conflict and agreed to be interviewed All other group members, including those who were allegedly directly involved, reported no problems within the group and requests for interviews were declined.

\section{Research Design}

Before the study abroad experience, there was no preconceived research agenda. However, seeking to more fully understand the issue of intragroup conflict that emerged, the program coordinator (researcher) made the decision to develop and analyze three narrative-based case studies (see Yin, 2003). This choice was influenced by the:

- Lack of previous empirical studies of conflict in short-term study abroad and conational groups

- Need to collect data in a natural setting

- Need to understand the nature intragroup conflict within co-national groups 
These reasons are consistent with the main reasons suggested by Benbasat, Goldstein and Mead (1987) for using case study method. This decision made with the knowledge the small sample offers little ground for proving reliability or generality of findings (Abercrombie, Hill \& Turner, 1984). Nevertheless the researcher believed the findings would be an important starting point for further exploration and revelatory study. The aims of the case studies were to:

- Present and analyze the experiences of three students;

- Understand the cause and effects of intragroup conflict identified; and

- Recommend ways to better prepare students to work in co-national groups and deal with intragroup conflict.

Case-study data included pre and post study abroad surveys, interview transcripts, and weekly journal entries. Added to this, were notes from Skype sessions -Ming Li (6) and John (4)- plus 63 emails -Ming Li (32), Kerry (20) and John (11). As agreed with the students before each Skype session, researcher notes were made and forwarded to the student for clarification and verification of content.

The different methods allowed the students to explain their views and experiences freely and spontaneously. The researcher's task was to find patterns and identify categories within those words and to present them in a coherent way for others to inspect. An individual student narrative-explanatory story- (Polkinghorne, 1995) helped achieve this objective.

\section{Narrative Development}

From the raw data, the researcher and each student collaborated in writing a story about their study abroad experience. Stories -narratives- helped describe and give meaning to the student's thinking and action (Lieblich, Tuval-Mashiach \& Zilber, 1998).

The stories included examples of specific personal and group happenings. These helped preserve the idiosyncratic nature of the data (Polkinghorne, 1995). Each student used written commentary to explain different parts of their story. To ensure accuracy each student reviewed and refined the final draft of the study abroad story.

\section{Analysis of Data}

Data analysis began by asking simple questions about the conflict, preparation and support and identifying evidence in response. More complex questions followed about identity, development and change. Evidence (data) from the 3 case studies were then collated and analyzed. The students and an independent academic colleague checked both individual and cross-case findings for authenticity (Lincoln \& Guba, 1985).

\section{Findings}

Ming Li, Kerry and John had all been studying English as a second language for 10-years or more. Ming Li believed herself to have well developed second language skills honed during family holidays in the United States of America (USA) and the United Kingdom (UK). In addition, she had taken part in two short-term international field trips to the UK during her secondary schooling. Ming Li like Kerry and John had traveled throughout Asia with family. Only Kerry had traveled as an individual.

Kerry and John believed they had much to learn about the use of English in academic contexts, notably in the areas of academic reading and writing. Despite academic results, John felt his oral language also needed "much improvement in formal presentations." Excerpts from 
Ming Li, Kerry and John's stories show the effects of intragroup conflict on their participation and identity development during the short-term study abroad program.

\section{Orientation}

Ming Li walked that Sunday morning flanked by strangers from the warmth of the airport, from the security of her home group, from the smells of coffee and toast, into the Canadian winter for the first time. Snow was falling, car lights blazed in the mid-morning light, creating a mosaic of colors against a gray concrete backdrop. That day cold Arctic air had invaded from the North and hit head on with the warmer moist air pushing up from the Gulf of Mexico. The resulting snow fell by the bucket load, and temperatures well below freezing. Tightening her scarf she waited "curbside" as directed; turning her face into the biting wind, she smiled. This was one thing she had looked forward to. One thing she had planned for. ... Face to the wind, her tiny frame shielded like a butterfly in a cocoon. Her eyes closed and a montage of home filled her; steaming chicken and rice, smiling faces, her parents, and the warmth of their combined love. It was all working perfectly. She felt strong within herself, within this shield, safe and secure, and to her parents she offered an unspoken word of thanks. This is a great start she thought. This is where I want to be. Ming Li learned however that not everyone was as happy.

The cold affected the group and they were forced indoors, forced to endure long afternoons and evenings with homestay families. When they were together the group reveled in complaining about the weather, the subway, of shopping, comparisons of homestay families, the food. They constantly whined about missing the dry warmth of the Hong Kong winter, the familiarity of family, friends and surrounds. The differences were the focus and this annoyed Ming Li. She felt the compulsion to defend the host country. The continuous comparisons, the longing to be home and out of the insistent cold and this program was understandable, and while she too had times of self-doubt, and forced herself not to linger on them, they it seemed could not.

She reflected:

I hated to hear their hatred. I couldn't stop asking myself, why don't they put more focus on planning goals and trips in Canada and looking for fun in proactive ways? At the time and now, I just felt it was reasonable. When people are settling in a new place, why is it that they need to cling together to form groups for strengthening their sense of security. How to connect to one another? One of them starts to express hatred and the rest follow the discussion.

\section{Identity: Who am I?}

Ming Li, Kerry and John embarked on the study abroad experience with clear goals and expectations.

John: I was raised to be independent, to speak my mind. I realize this is unusual for a Chinese person, but my parents encouraged me to think this way. As a result, I am confident, some say 'opinionated' and passionate, and I am strong in my sense of self who I am, what I am doing and why. 
Kerry: I quietly confident. I hate people who make a fuss about using others who use English, like many in Hong Kong. My parents cannot speak English, but they insisted I learn and made me attend afternoon tutorial classes all through my primary and secondary school.

\section{Group conflict: program purpose}

In the first week it became clear that Ming Li, Kerry and John had a different view about the program to others in their group. They each found themselves defending the program and local culture. Each had heated arguments with different group members about the purpose of the program, as highlighted in Kerry's Week 4 e-journal entry.

Kerry: They feel they are being forced into this program, forced to endure a foreign culture, forced to leave their home. They do not buy into the program goals. They believe their English language and intercultural skills are good enough, for after-all their home "is a multi-cultural city" as they keep reminding me. But I have seen them. They stay together; they're always speaking Cantonese, always heading off to Chinatown, not engaging with local staff or students, even in classes they stick together.

\section{Identity development}

The negative exchanges forced Kerry to think about herself and her identity.

Kerry: My look was taken by an old woman leaning uncomfortably against the door, the ragged, torn clothes, and the smell of alcohol. She shifted awkwardly against the sway of the train and a black man said something which was ignored. Her friend's laughter, too loud, the incessant, smiles and chatter, it was all happening so fast, all at once. Who am I? What is my place here? The surrounds are familiar, but it is me who is different. She'd seen the looks, the quiet giggles and talks in her direction, the look-away stares at the briefest eye contact. How could she, would she ever be able to make sense of this? For the first time in her life she was the odd one out. I am the minority, she reflected, the different one; she was not sure she liked this.

Feelings of isolation and confronting cultural differences are common for study abroad students. She turned to her co-national group for support. However, instead of drawing comfort Kerry felt increasingly ostracized because of the differences in academic and socio-cultural expectations. Local Canadians on the other hand treated her with respect and understanding.

Whenever I opened my map and got ready to read, strangers would take initiative and help me within 5 seconds. This is a cultural feature of Canadians and something not common in the Hong Kong Chinese culture. But why not? I need the help, and they provide it willingly. Why should we as Chinese think foreigners do not need our help? What makes us so different, so distant, and so different?

\section{Fitting in}

John had been warned against getting too involved in the program and with local people. It was never his intent to cause rifts between himself and the co-national group, and he felt deeply hurt when it did happen. For Ming Li, Kerry and John fitting into another culture was 
easier to talk about than to do. It was not the new culture that was the issue; it was people from their own cultural group who proved the greatest obstacle to fitting in. In the first month, they slowly lost the support of the group. Ming Li, Kerry and John took to Canada a determination to learn as much as they could about Canada and Canadian culture. They wanted to make as many new acquaintances as they could and develop an understanding of Canadian language, including its slang (John). All three wanted to learn to use Canadian English like native speakers. For Ming Li especially, the growing lack of co-national group support led to periods of depression and self-doubt.

Ming Li: Shutters drawn on darkened mall shops, a whirring floor polisher in the distance. Her notebook open on the rounded coffee table, a menu empty of Chinese, food, worn lounge chairs sat in forlorn emptiness. Ming Li typed in the humming silence. She felt isolated and culturally drained; her plans and goals were coming undone, $12,000 \mathrm{kms}$ from her family and friends. The thought of quitting the program surfaced and distracted her. The family would understand, but could she... Quitting was not something she had experienced and she had so much invested in this ...eyes closed, she recalled the advice of a friend who had been involved in a study abroad program. "You must be yourself, seek what you like and trust your instincts." And with this her quiet inner resolve returned. She'd stick it out, despite the cost, and she'd seek support when and from whom it was offered.

\section{Intragroup conflict}

On many occasions the whole group would dine together in Chinatown. But increasingly Ming Li and Kerry, and to a lesser extent John refused to join, preferring to mix with an increasing number of local friends from whom they could learn about the culture and practice their intercultural interaction skills. However, they were ill prepared for the exchanges that were to come: starting with a phone call to each of them

Translation: "We need to talk"

From the tone they knew this was not to be a friendly chat.

John's e-journal records the conversation:

"Over the past months you guys have been isolating yourself from the group. We invite you to hotpot, to go shopping, to join us to watch Hong Kong and Chinese films on YouTube and you refuse us."

"Even you John, you don't even sit with us in class anymore" “"

"What's going on?"

Ming Li's e-journal and Skype to the coordinator shows how she tried to explain:

Ming Li: Look it's simple. I don't have money for shopping. I want to try local traditional food not Chinese. The Chinese food is expensive and Canadian-Chinese style, I don't like it. I want to explore everything I can about Canada. You know I want to learn about Canada ...the only way I see to do this is total immersion. If I give in just a bit, I know myself, I may as well give in altogether. I must grab the chance, every opportunity while I can.

Group member's response: "You're being selfish ...you're all being selfish. You overappreciate Western culture ... you are disgusting you even like Western junk food 
'beavertail' ... you forget you are Chinese, you are "sung yeung" - worshippers of Westerners.

Kerry's e-journal reflected on the exchanges that day:

Kerry: It was my darkest day ever in my life. When 'sung yeung' was mentioned and appeared again many times in emails from group members; tears came. How could my so-called friends hold such a view? How could they so obviously look down on me and the others and this other culture? How can they be so narrow-minded? It's them who are being self-centered, culturally centered.

\section{Getting personal}

Following the group confrontation, e-journal entries, emails and Skype sessions reinforced the sentiments expressed in the discussion. They also reveal how the nature of the early conflicts transformed from what until that point had been conflicts about differences and decisions about the program -tasks and their involvement- to more personal relationship conflict.

Ming Li: The confrontation hurt deeply. Her eyes stung from the tears, and she avoided the stares of those on the bus, ignored the bus driver's daily pleasant greeting. She hid her head as best she could inside her hat. The familiar apple shampoo smell of the lining was of little comfort. Had she got it wrong? Why were they so nasty to her? It wasn't personal, but they were making it so. She had not asked for their support nor did she need their approval ...but they saw it differently. By doing what she felt the program was designed for and encouraged she was seen by them as betraying her kind ... How is this possible. I am a proud Hong Kong Chinese girl and nothing will change that.

\section{Intragroup conflict resolution}

In literary stories, conflicts are mostly resolved. In Ming Li, Kerry and John's cases, personal goals and the intragroup conflict led to a strengthened sense of purpose, increased bonding with homestay hosts and students from the host culture. Despite the conflicts, their personal and socio-ethnic identity while tested had remained if not strengthened. To survive the conflicts they found support in one another and local students.

Kerry: I was lucky though. I found Ming Li and John. They knew each other but were never close in or outside class. I had never really spoken with them directly in their time at university, yet I found they shared similar goals and interests. With their help and that of her Canadian friends she became more determined to see this program out. And no matter what the group thought, she would achieve her goals. In the early hours of one night, after hot chocolate with her homestay dad and in the darkness she reflected. I will try and create a more balanced approach where the group is concerned ...if that is possible. I will try and spend a little more time with them ...try and evaluate things productively from both sides. 
On return to Hong Kong, analyses of post study abroad interviews show some positive outcome of the intragroup conflict. It strengthened their second language identities, their view of themselves as learners and users of English as a second language.

Ming Li: I am more confident, a better problem solver. My use of English both at the university and with locals improved a lot. I am more open to people and to those who are different. As a person, a second language user and learner, I know I have the skills needed to interact with native speakers of English or who come from different cultures. I have developed my second language skills, especially in speaking and I am more tolerant and giving. I have gained in wisdom.

Kerry: The negative experiences have increased my ability to integrate with and deal with issues related to interacting with English speaking people. I now see myself as a more open-minded and culturally tolerant Hong Kong Chinese person. I wish others here [in Hong Kong] could be more like this also. At the time it was difficult, dealing with the group, however I have been positively shaped by those experiences.

John: The conflict forced me to integrate with local Canadians. This helped me to develop my use of academic English and skills to integrate and interact. I feel more confident as a person and as a student. I feel sorry for most of my group members. They failed to take advantage of this special opportunity; they live in safety of their Hong Kong Chinese identity and are satisfied with their English language skills. But as they showed, these skills are far from good enough, especially in an academic school environment. And to think they will be teachers influencing children in the future. It's sad for them and their students.

\section{Discussion}

Ming Li, Kerry and John had a rewarding yet confronting short-term study abroad experience. While each had regular contact with their support networks at home, adjusting to the new academic and social environments, and living with the immediacy of decisions and actions proved challenging. Fortunately, from the outset, they were confident in their ability to adapt and to interact with native English speaking people. A confidence supported in part by previous travel experience and a belief that if tough times arose, they could find support in their small conational study abroad group. However, as they each discovered, fitting in with this small conational group would prove to be the greatest challenge of their study abroad experience.

\section{Nature and effects of intragroup conflict}

From the start of weekly journal entries each student reported differences between the way the co-national group was reacting to the study abroad experience and their own thinking and action. At first these were about "simple things" like the weather, homestay families, lack of Chinese food and program content. Ming Li, Kerry and John had independently thought about and planned for such events. Over the weeks, differences between them and the co-national group intensified. They found themselves increasingly defending Canadian life, the study abroad environment and themselves. 
While abroad the co-national group had several classes together, away from host nationals. This, in Ming Li's opinion, reinforced the use native Cantonese language and existing group relations. In hindsight, Kerry believed the group took exception to their positive nature and insistence on engaging in study abroad tasks. These she believed threatened co-national group practices.

Jehn's (1995) distinction between task conflict and relationship conflict provides some insight into the nature of the conflict experienced. At first Ming Li, Kerry and John and other students in her co-national group differed in their reactions to the study abroad context and the perspectives, opinions, and ideas about the intercultural nature of the program purpose. There were also differences in understanding of the program purpose and emerging views of cultural bias -task conflict (Jehn, 1995) within the group. Task conflicts increasingly became more personal, resulting in relationship conflict (Jehn \& Mannix, 2001). The co-national group began to question and make comments about their motives for engaging with local students. The group eventually openly challenged their social-ethnic (Chinese) identity. The shift from task to highly personal relationship conflict frustrated Ming Li, Kerry and John. It led to negative emotions, and personal reflection on their views of the program, what it meant to be Chinese and personal motives. The conflict forced Ming Li, Kerry and John, in their own way to consider "quitting the program." On reflection Ming Li and Kerry believed what stopped them was the strength of their inner strength -personal identity- and the support received from family and local student friends.

While task conflict can have a positive effect on co-national group relations (Jehn, Greer, Levine \& Szulanski, 2008), relationship conflict proved to be the opposite. Ultimately, it led to social segregation from the co-national group. This affected their involvement in the program and to different degrees their self-esteem and psychological well-being. Had it not been for welldeveloped personal identities, the end-result may have been different.

Ming Li, Kerry and John each experienced "identity deficit" (Baumeister, 1986) when co-national group views of task and intercultural relations conflicted with their own. Co-national group members questioned and challenged their insistence on speaking English and developing social contact and friendships with host nationals. Others insisted they conform and preserve conational group boundaries - "to stick together" as Hong Kong born Chinese. Independently, each fought with the group about what they believed were discriminatory comments about themselves and local people. Their actions tested the permeability of the co-national group boundaries and the sensed discrimination became, as Lin (2008) also found, "powerful and effective" predictors of the resulting conflict. What is new in these case studies is that these predictors were directed by a co-national group toward members of their own ethnic group as opposed to host nationals in Lin's study. The strength of Ming Li, Kerry and John's personal and social-ethnic identities was greater than the loyalty felt toward their co-national group.

At the heart of the intragroup conflict experienced by Ming Li, Kerry and John were differences in perceptions of program purpose and acculturation strategies. Despite the program length, Ming Li, Kerry and John's pre-departure interviews and goal setting signaled each had a wish to learn as much as possible about Canadian culture. This goal included making local friends, joining in classes, traveling and socializing with their host families and university peers. Sixty percent of their co-national group shared similar goals. However, while Ming Li, Kerry and John acted on their goals, others either did not have the skills or personal commitment to do so.

In 1997, Berry proposed a model of 4 different acculturation strategies: marginalization, separation, assimilation, and integration. As discussed, Ming Li, Kerry and John's narratives 
show strong personal ethnic identities and a keen interest in learning about the new culture thorough daily integration with other groups -integration strategy. The intragroup conflict, according to the three students, came about because other members of their co-national group wanted to separate themselves from local people and culture -separation strategy. The group placed great value on holding on to their Hong Kong Chinese culture, while separating themselves whenever possible from the new culture. Without data from the individuals in this group, there is no way of knowing whether or why the difference in acculturation strategy occurred. From the data collected, however, it appears the co-national group believed the three were reducing ties with their native culture and through daily interaction gravitating to the new culture -assimilation strategy.

The integration strategy may be seen as more favorable for students on short-term study abroad programs. It allows students to learn from the new culture while also preserving their ties with their native culture; in essence achieving the best of both worlds. Future research and study abroad preparation programs should consider examining theoretically and in practice the nature and use of acculturation strategies. Such research would provide institutions and students with the understandings on which to discuss or understand conflicts and actions of others. Research that may also explore the possibility of synthesizing the relative merits of two dimensions assimilation and separation- into a more flexible and adaptive acculturation strategy. One in which students don't need to reject either culture, but can interact with both cultures in adaptive and positive ways.

\section{Preparation and support}

From Ming Li, Kerry and John's experience, there was a lack of program preparation and support. Their pre-departure preparation, according to Ming Li, was "a half-day orientation, which was mostly about administrative matters." Parents, institutions and students invest heavily in study abroad. Therefore, to ensure a positive academic and social and cultural return, greater emphasis should be placed on preparing study abroad students traveling alone or in groups to ensure they have a positive study abroad experience.

A comprehensive pre-study abroad preparation course (see Benson et. al., 2013) may have helped Ming Li, Kerry and John in several ways. All students would have taken part in tasks and opportunities which:

a. Aid in developing an understanding of the program purpose

b. Examine past second language learning and develop intercultural skills and understanding

c. Strengthen their ability to cope with the stresses and potential cultural, task and relationship conflicts that may arise. Such conflict and mediation exercises would also help improve the quality of student's decision-making and actions

d. Help all members of the co-national group to understand and develop a greater respect for -if not acceptance of- individual differences both within the group and for those outside it

While Ming Li, Kerry and John's narratives signal support by the researcher, there are no references to host program coordinator support. This lack of support may be seen as a failure in the host institutions 'duty of care' to oversee and actively address student involvement and welfare. In addition, all study abroad students need to be made familiar with the host institution's protocols for getting support from specialist units or people such as counselors to whom they can 
consult. Such support must be integral to the continuing support offered before, during and after the study abroad program (Benson et. al., 2013).

\section{Conclusion}

The world over, students are increasingly taking part in study abroad programs. To deal with the stresses associated with study abroad, students often seek and find support from co-national groups. However, when problems within such groups move from task to relationship conflicts, individual students like those reported in this article, may experience social or cultural isolation. This can add to the student's psychological and sociocultural stresses of acculturation. To cope, students need support from friends, family and the host institution. If such support is missing or the student's needs go unnoticed, and under the pressures of study abroad, the results for some students could be more tragic.

The experiences of these students reveal the need for planned and continuing support -before, during and after a study abroad program. Their case studies are an important starting point for further exploration and revelatory study into student's acculturation strategies, the nature of co-national groups, and intragroup conflict.

\section{REFERENCES}

Abercrombie, N., Hill, S., \& Turner, B .S. (1984). Dictionary of sociology. Harmondsworth, UK: Penguin.

Al-Sharideh, K. A., \& Goe, W. R. (1998). Ethnic communities within the university: An examination of factors influencing the personal adjustment of international students. Research in Higher Education, 39, 699-725.

Baumeister, R. F. (1986). Identity: Cultural change and the struggle for self. New York: Oxford University Press.

Benbasat, I., Goldstein, D. K., \& Mead, M. (1987). The case research strategy in studies of information systems. MIS Quarterly, 11(3), 369-386.

Benson, P., Barkhuizen, G., Bodycott., \& Bell, J. (2013). Second language identity in narratives of study abroad. Hampshire, UK: Palgrave Macmillan.

Berry, J. W. (1997). Immigration, acculturation, and adaptation. Applied Psychology: An International Review, 46 (1), 5-68.

Berry, J. W. (2002). Conceptual approaches to acculturation. In K.M. Chun, P. Organista \& G. Marin (Eds.), Acculturation: Advances in theory, measurement and applied research (pp. 17-38). Washington, DC: American Psychological Association.

Bochner, S., McLeod, B. M., \& Lin, A. (1977). Friendship patterns of overseas students: A functional model. International Journal of Psychology, 12(4), 277-294.

Bodycott, P., \& Crew. V. (2000). The value of short-term overseas English language immersion courses. The Language Teacher, 24(9), 27-33.

Bodycott, P., Mak, A. S., \& Ramburuth, P. (2014). Utilizing an internationalized curriculum to enhance students' intercultural interaction, engagement and adaptation. Asia-Pacific Education Researcher, 23(3), 635-643.

Chen, C. P. (1999). Common stressors among international college students: Research and counseling implications. Journal of College Counseling, 2, 49-65. 
Dempsey, A. (2012). Cross-cultural Interactions of Chinese graduate students at a midsized U.S. university. (Electronic Thesis or Dissertation). Retrieved from https://etd.ohiolink.edu/

Ethier, K. A. \& Deaux, K. (2001). Negotiating social identity in a changing context: Maintaining identification and responding to threat. In M.A. Hogg \& D. Abrams (Eds.), Intergroup relations (pp. 254-266). Philadelphia: Psychology Press.

Jehn, K. A. (1995). A multi-method examination of the benefits and detriments of intragroup conflict. Administrative Science Quarterly, 40, 256-82.

Jehn, K. A., Greer, L. L., Levine, S., \& Szulanski, G. (2008). The effects of conflict types, dimensions, and emergent states on group outcomes. Group Decision and Negotiation, 17, 465-495.

Jehn, K. A., \& Mannix, E. (2001). The dynamic nature of conflict: A longitudinal study of intragroup conflict and group performance. Academy of Management Journal, 44, 238251.

Kelly, G. A. (1955). The psychology of personal constructs. New York: Norton.

Kim, Y. Y. (2001). Becoming intercultural: An integrative theory of communication and crosscultural adaptation. Thousand Oaks, CA: Sage.

Kinginger, C. (2009). Language learning and study abroad: A critical reading of research. New York: Palgrave/Macmillan.

Kinginger, C. (2010). American students abroad: Negotiation of difference. Language Teaching, 43(2), 216-227.

Leong, C. H., \& Ward, C. (2000). Identity conflict in sojourners. International Journal of Intercultural Relations, 24, 763-776.

Lieblich, A., Tuval-Mashiach, R., \& Zilber, T. (1998). Narrative research: Reading, analysis and interpretation. Thousand Oaks, CA: Sage.

Lin En-yi. (2008). Family and social influences on identity conflict in overseas Chinese. International Journal of Intercultural Relations, 32, 130-141.

Lincoln, Y.S., \& Guba, E.G. (1985). Naturalistic inquiry. Beverly Hills, CA: Sage.

Llamas, J. D., \& Consoli, M. (2012). The importance of familia for Latina/o college students: Examining the role of familial support in intragroup marginalization. Cultural Diversity and Ethnic Minority Psychology, 18(4), 395-403.

Mak, A. S., \& Kim, I. (2011). Korean international students' coping resources and psychological adjustment in Australia. OMNES: The Journal of Multicultural Society, 2(1), 56-84.

Maundeni, T. (2001). The role of social networks in the adjustment of African students to British society: Student's perceptions. Race, Ethnicity and Education, 4, 253-276.

Mayer, C. H. (2009). Managing conflicts through strength of identity. Management Revue, 20(3), 268-293.

Medina, F. J., Munduate, L., Dorado, M. A., \& Guerra, J. M. (2005). Types of intragroup conflict and affective reactions. Journal of Managerial Psychology, 20(3-4), 219-230.

Milstein, T. (2005). Transformation abroad: Sojourning and the perceived enhancement of selfefficacy. International Journal of Intercultural Relations, 29, 217-238.

OECD. (2013). How is international student mobility shaping up? Education indicators in focus, (No. 14). Paris: OECD Publishing. DOI: 10.1787/5k43k8r4k821-en

Pitts, M. J. (2009). Identity and the role of expectations, stress, and talk in short-term student sojourner adjustment: An application of the integrative theory of communication and crosscultural adaptation. International Journal of Intercultural Relations, 33(6), 450-462. 
Polkinghorne, D. E. (1995). Narrative configuration in qualitative analysis. International Journal of Qualitative Studies in Education, 8(1), 8-25.

Swann, W. B. Jr., \& Bosson. J. (2008). Identity negotiation: A Theory of Self and Social Interaction. In O. John., R. Robins \& L. Pervin (Eds.), Handbook of personality psychology: Theory and research (pp. 448-471). New York: Guilford.

Tajfel, H., \& Turner, J. C. (1986). An integrative theory of inter-group conflict. In S. Worchel., \& W. Austin (Eds.), Psychology of inter-group relation (pp. 2-24). Chicago: Nelson-Hall.

Trice, A. G. (2007). Faculty perspectives regarding graduate international students' isolation from host national students. International Education Journal, 8(1), 108-117.

Ward, C., \& Kennedy, A. (2001). Coping with cross-cultural transition. Journal of Crosscultural Psychology, 32(5), 636-642.

Ward, C., \& Searle, W. (1991). The impact of value discrepancies and cultural identity on psychological and sociocultural adjustment of sojourners. International Journal of Intercultural Relations, 15, 209-225.

Williams, C. T., \& Johnson, L. R. (2011). Why can't we be friends? Multicultural attitudes and friendships with international students. International Journal of Intercultural Relations, 35, 41-48.

Woolf, M. (2007). Impossible things before breakfast: Myths in education abroad. Journal of Studies in International Education, 11, 496-509.

Yin, R. K., (2003). Case study research: Design and methods $\left(3^{\text {rd }}\right.$ ed.). Thousand Oaks, CA: Sage.

\section{About the Author}

PETER BODYCOTT, PhD, is a Professor of Education in the Faculty of Education, Science, Technology \& Mathematics at the University of Canberra, Australia. He has worked as an elementary school teacher and as an academic teaching and researching extensively in Asia. He has held positions at the Hong Kong Institute of Education, the National Institute of Education, Nanyang Technological University in Singapore and at the University of Wollongong, Australia. His teaching specializations include intercultural adaptation, internationalizing higher education, teaching in early and middle years, literacy education and English as a second language. His research interests include internationalization of the curriculum, second language identity development, study abroad, international education policy and practice, intercultural education, ESL and literacy education. Email: peter.bodycott@canberra.edu.au 